\title{
Antidiabetic Activity of Pereskia Bleo Aqueous Extracts in Alloxan Induced Diabetic Rats
}

\author{
Mat Darus NA and Mohamad J* \\ Institute of Biological Sciences, Faculty of Science, University of Malaya, 50603 Kuala \\ Lumpur, Malaysia
}

*Corresponding author: Jamaludin Mohamad, Institute of Biological Sciences, Faculty of Science, University of Malaya, 50603 Kuala Lumpur, Malaysia, E-mail: jamal@um.edu.my

\section{Research Article}

Volume 1 Issue 7

Received Date: September 18, 2017

Published Date: October 04, 2017

\begin{abstract}
Pereskia bleo Kunth (Cactaceae) is locally known as 'Jarum tujuh bilah'. It has been used traditionally by local Malays for the treatment of diabetes. This study investigates the antidiabetic activity of aqueous extract of Pereskia bleo. The leaf, stem, and root aqueous extracts of Pereskia bleo were evaluated for total phenol and flavonoid contents. The in vitro antioxidant activity was evaluated using DPPH, FRAP and metal chelating assay. The in vivo antidiabetic activity was determined in alloxan induced male Sprague Dawley rats. The LCMS/MS analysis revealed the presence of apigenin 6 glucoside and chrysin. The total phenol and flavonoid contents were highest in the stem aqueous and chloroform extracts at $6.05 \pm 0.10 \mathrm{mgGAE} / \mathrm{g}$ and at $11.07 \pm 0.20 \mathrm{mgGAE} / \mathrm{g}$ respectively. The alloxan induced diabetic rats showed that the leaf, stem and root aqueous extract at $500 \mathrm{mg} / \mathrm{kg}$ decreased significantly with fasting plasma glucose level by $66 \%, 65 \%$ and $58 \%(\mathrm{p}<0.001)$ respectively on the $25^{\text {th }}$ day compared from day zero. It also showed decreased in the total cholesterol, triglycerides and restored the HDL level. The liver function test indicated no significance difference in ALT, AST and ALP. Thus, it is concluded that the Pereskia bleo possessed the antioxidant and antidiabetic activity attributed by the presence of apigenin 6 glucoside and chrysin.
\end{abstract}

Keywords: Anti-diabetic; Jarum Tujuh Bilah; Apigenin; Chrysin

Abbreviations: TLC: Thin Layer Chromatography; LCMS: Liquid Chromatography Mass Spectrometry; MS: Mass Spectroscopy; PB: Pereskia bleo; ALT: Alanine Aminotransaminase; AST: Serum Aspartate Aminotransaminase; ALP: Alkaline Phosphatase; TC: Total Cholesterol; TG: Triglycerides

\section{Introduction}

The use of medicinal plants for treating diabetes has encouraged researchers to develop natural drugs to control blood glucose homeostasis without the inherent side effects. The plant kingdom provides numerous plant species that allow for the research of natural as well as an effective oral hypoglycemic agent without the side effects. Currently, more than 400 plants possessing glucose lowering effects are known [1]. A number of researches have shown that flavonoids, terpenoids and alkaloids possess hypoglycemic effects in induced diabetic rats [24]. The Pereskia bleo Kunth (Cacteceae) has been traditionally used to treat diabetes [5]. However, presently there is yet to be any study concerning its antidiabetic activity that has been reported in alloxan induced diabetic rats. It is commonly known as "jarum tujuh bilah" 


\section{Open Access Journal of Pharmaceutical Research}

and characterized by its spiny shrubs and distinct orangecolored flowers. Pereskia bleo has thin, corrugated leaves and orange-red flower with shorter spines [6,7]. The leaves of this plant are regularly consumed as raw salad by the Malays and have been traditionally $u$ as a form of herbal medicine for the treatment of cancer-related diseases, high blood pressure, diabetes, rheumatism and inflammation. It has also been claimed that Pereskia bleo possesses antitumor, antirheumatic, antiulcer, anti inflammatory and anticancer activities. Sri Nusrestri, et al. [8] reported that Pereskia bleo cytotoxic affects selected human carcinoma cancer cell lines and revealed that compound 2,4-di-tert-butylphenol possessed very a remarkable cytotoxic activity against KB cells [8]. The acute and oral toxicity in experimental ICR mice by Sim, et al. has been revealed that there were no mortality and adverse effects on the mice when induced with Pereskia bleo and Pereskia grand folia Haworth (Cacteceae) [9]. Pereskia bleo has also been shown to possess significant antioxidant activity due to the presence of phenol and flavonoid compounds $[10,11]$. Nevertheless, there was no scientific evidence for the antidiabetic property of Pereskia bleo reported. Thus, the present work was undertaken to evaluate the antidiabetic potential of Pereskia bleo in alloxan induced diabetic rats.

\section{Materials and Methods}

\section{Collection of Plant Sample}

The leaves, stems and roots of the Pereskia bleo were collected in July 2015 from the Botanic Garden, Faculty of Science, University of Malaya, Malaysia. Its authenticity was confirmed and identified by a plant taxonomist, Professor Dr. Ong Hean Chooi from the Institute of Biological Sciences, Faculty of Science, University of Malaya. The voucher specimens were deposited in the herbarium of the Institute of Biological Sciences, Faculty of Science, University of Malaya, Kuala Lumpur, Malaysia, with voucher numbers of SN01-06.The samples were dried in the oven at $40^{\circ} \mathrm{C}$, then grounded into a fine powder and kept in an airtight container for extraction purposes.

\section{Preparation of Extracts}

$30 \mathrm{~g}$ of the powder sample of leaves stems and roots were extracted with $100 \mathrm{~mL}$ of water. Then the mixture was incubated in a water bath at $40^{\circ} \mathrm{C}$ for 2 hours. After the incubation, the mixture was filtered and the aqueous extract was concentrated to dryness using a vacuum rotary evaporator at $40^{\circ} \mathrm{C}$.

\section{Separation and Detection of Chemical Compounds}

The chemical compounds of the aqueous extract were separated with Thin Layer Chromatography (TLC). The extract was loaded as a band onto TLC plate size $20 \mathrm{~cm} \mathrm{x}$ $20 \mathrm{~cm}$ using capillary tube. The TLC separation was developed in a chromatography tank in the chloroform solvent system. The presence of phenols, terpenoids and alkaloids were detected with phenol, vanillin $\mathrm{H}_{2} \mathrm{SO}_{4}$ and Dragendroff reagent respectively. The liquid chromatography mass spectrometry/mass spectroscopy (LCMS/MS) of the bioactive compound of aqueous extract was determined with column Phenomenex aqua C18$50 \mathrm{~mm} \times 2.0 \mathrm{~mm} \times 5 \mu \mathrm{M}$.

\section{Determination of Total Phenols}

The total phenolic content of aqueous extracts was determined with the Folin-Ciocalteu reagent using the methods from Spanos \& Wrosltad [12]. First, the FolinCiocalteu reagent was dissolved in distilled water with a 1:10 ratio. The crude extracts $(500 \mu \mathrm{L})$ were mixed with 5 $\mathrm{mL}$ of Folin-Ciocalteu reagent and $4 \mathrm{~mL}$ of $1 \mathrm{M}$ sodium carbonate $\left(\mathrm{Na}_{2} \mathrm{CO}_{3}\right)$. The reaction mixture was incubated in a water bath at $45^{\circ} \mathrm{C}$ for 15 minutes. The absorbance of the sample was measured at $765 \mathrm{~nm}$ with a spectrophotometer. The total phenol content was determined using a standard curve prepared from 0,50 , $100,150,200,250$ and $500 \mathrm{mg} / \mathrm{L}$ of gallic acid in methanol solution $(50: 50 / \mathrm{v}: \mathrm{v})$. The results were expressed as milligram of gallic acid equivalent per gram of dry sample. All of the aqueous extracts were tested in duplicate and the mean value was calculated.

\section{Determination of Total Flavonoids}

The total flavonoid content of the extracts was determined using Aluminium chloride colorimetric method with a slight modification as described by Liu, et al. [13]. The standard concentration samples $(10 \mathrm{mg} / \mathrm{mL})$ in methanol (1:1) were mixed with $0.3 \mathrm{~mL} 5 \%$ sodium nitrate and incubated for $5 \mathrm{~min}$ at $37^{\circ} \mathrm{C}$. $0.3 \mathrm{~mL} 10 \%$ aluminuim chloride was added and incubated $6 \mathrm{~min}$ at $37^{\circ} \mathrm{C} .2 \mathrm{~mL}$ of sodium hydroxide and $10 \mathrm{~mL}$ distilled water was added. Absorbance was measured at $510 \mathrm{~nm}$ using a spectrophotometer. The total flavonoids content was determined using a standard curve prepared from 0,50 , $100,150,200,250$ and $500 \mathrm{mg} / \mathrm{L}$ of quercetin. The results were expressed as $\mathrm{mg}$ of quercetin equivalent per gram of dry sample. 


\section{Open Access Journal of Pharmaceutical Research}

\section{Animal Studies}

The male Sprad Dawley rats aged 2 months and weighing 120-150g were used for the study. The animals were kept in rat cages of six rats per cage and maintained under standard conditions at $12 \mathrm{~h}$ light and $12 \mathrm{~h}$ dark cycle, room temperature $30^{\circ} \mathrm{C}, 70-80 \%$ relative humidity. They were fed with standard rat pellet diet and water $a d$ libtium. The animal study was carried out under Animal Ethics Committee of Animals House, Faculty of Medicine, University of Malaya with animal ethic No: ISB/05/05/2010/NAMD (R).

\section{Acute Toxicity Study}

The Sprague Dawley rats in a group of six rats were starved overnight. They were fed with the extracts at the doses of $0.2 \mathrm{~g} / \mathrm{kg}, 0.5 \mathrm{~g} / \mathrm{kg}$ and $1 \mathrm{~g} / \mathrm{kg}$ body weight. The acute toxicity study was carried out according to OECD guidelines - 423 [14]. The toxic effect on alertness, restlessness, irritability, fearlessness, spontaneous activity, defecation and urination were observed continuously for 14 days to record any lethality or death.

\section{Oral Glucose Tolerance Test (OGTT)}

The oral glucose tolerance test was carried out according to Shirwaikar, et al. [15]. The normal rats were fasted overnight. The rats were divided into six groups consisting of six rats in each group and administered with glucose $(3 \mathrm{~g} / \mathrm{kg})$, glipizide $(3 \mathrm{mg} / \mathrm{kg})$, leaves, stems and roots aqueous extract at $0.2 \mathrm{~g} / \mathrm{kg}, 0.5 \mathrm{~g} / \mathrm{kg}$ respectively. The glucose $(3 \mathrm{~g} / \mathrm{kg})$ was fed $30 \mathrm{~min}$ after the administration of the extracts. Blood was withdrawn from the retro orbital sinus under ether inhalation at $0,30,60$ and $120 \mathrm{~min}$ of glucose administration. The glucose level was estimated using glucometer Accu check (USA) with glucose-oxidase-peroxidase reactive strips.

\section{Induction of Diabetes in Rat}

The rats weighing 120-150g were induced with $120 \mathrm{mg} / \mathrm{kg}$ of allozan by single intraperitoneal injection. Hyperglycemia was confirmed by the evaluated glucose level determined at $72 \mathrm{~h}$. Animals with a blood glucose level more than $216 \mathrm{mg} / \mathrm{dl}$ were considered as diabetic and were used for the antidiabetic study. Glipizide at $3 \mathrm{mg} / \mathrm{kg}$ was used as a standard drug.

\section{Antidiabetic Test}

The animals were divided into nine groups, consisting of six rats per group. The Group I: Normal control rats administered with saline. Group II; Diabetic control rats administered with saline. Group III; Diabetic rats administered with Glipizide $(3 \mathrm{mg} / \mathrm{kg})$ as standard drug. Group IV and V: Diabetic rats were administered with leaves aqueous extract at dose $0.2 \mathrm{~g} / \mathrm{kg}$ and $0.5 \mathrm{~g} / \mathrm{kg}$. Group VI and VII; Diabetic rats administered with stem aqueous extract at dose $0.2 \mathrm{~g} / \mathrm{kg}$ and $0.5 \mathrm{~g} / \mathrm{kg}$. Group VIII and IX: Diabetic rats administered with root aqueous extracts at doses $0.2 \mathrm{~g} / \mathrm{kg}$ and $0.5 \mathrm{~g} / \mathrm{kg}$. The treatments were administered for 25 days and the effects were observed by fasting blood glucose level, body weight, and lipid profile levels. Fasting blood glucose levels were taken on days $0,5,10,15,20$ and 25 of treatment administration. On day 25, the rats that starved overnight were sacrificed by cervical dislocation and blood collected. Blood glucose levels were estimated using glucometer (Accu- check PEFORMA). The lipid profile levels and renal test were measured in a commercial diagnostic laboratory using the equipment SIEMENS Dimension Vista ${ }^{\circledR}$ System (Laboratory Medicine, University Malaya Medical Centre)

\section{Results and Discussions}

The phytochemical separation and isolation of the chemical compounds from the aqueous extracts of leaves, stems and roots of Pereskia bleo with thin layer chromatography showed the presence of flavonoids compounds. The liquid chromatography mass spectroscopy and mass spectroscopy have revealed the presence of the flavonoid of apigenin 6-glycoside and chrysin (Figure 1). The Pereskia bleo extracts were also reported to have phenolic and flavonoid compound such as catechin, quarcetin, epicatechin, and myricetin in its leaves [10]. Table 1 shows that the aqueous extracts of the stem contained the highest phenol and flavonoid contents at $6.05 \pm 0.10 \mathrm{mgGAE} / \mathrm{g}$ and $7.86 \pm 0.07 \mathrm{mgQE} / \mathrm{g}$ respectively.In the acute toxicity test, there were no toxic sign such as restlessness, response to touch, fearfulness, urination or death found in male rats with any of the doses given to each rat until the end of the experimental works. The administration of aqueous extracts of Pereskia bleo (PB) was conducted intraperitoneally 30 min prior to glucose being loaded into the normal rats in OGTT, which showed improved glucose tolerance in normal rats. The magnitude of the effect varied with the dose being administrated. As shown in Figure 1, the higher dose of $0.5 \mathrm{~g} / \mathrm{kg}$ body weight of $\mathrm{PB}$ aqueous extracts significantly produces a maximum fall of glucose level measured at 120 min compared to the control group. The root of PB aqueous extracts at $0.5 \mathrm{~g} / \mathrm{kg}$ body weight produces a significantly maximum fall of $26.8 \%$ at 120 min after the glucose administration, followed by PB root aqueous extracts $(0.2 \mathrm{~g} / \mathrm{kg}$ body weight) $25.5 \%$, PB stem aqueous extract $(0.5 \mathrm{~g} / \mathrm{kg}$ body weight) $19.7 \%$, and $\mathrm{PB}$ 


\section{Open Access Journal of Pharmaceutical Research}

leaves aqueous extract $(0.5 \mathrm{~g} / \mathrm{kg}$ body weight) $17.5 \%$. In the PB stem aqueous extract $(0.2 \mathrm{~g} / \mathrm{kg}$ body weight $)$ and $\mathrm{PB}$ aqueous leaves extract $(0.2 \mathrm{~g} / \mathrm{kg}$ body weight $)$ there is no significant fall of blood glucose level. The group administrated with glipizide as a standard drug show similar percentages in the decrease of blood glucose level to PB leaves aqueous extract at dose $0.5 \mathrm{~g} / \mathrm{kg}$ body weight, while toxicity studies carried out on a dose $0.5 \mathrm{~g} / \mathrm{kg}$ body weight showed no adverse effects during the 7 days observation. Hyperglycemia is one of the important characteristics of diabetes mellitus. The alloxan induced diabetic rats treated with PB aqueous extract as shown in Table 2 showed a reduction in blood sugar level. There was a significant elevation in the blood glucose level in the diabetic control group compared to a normal control group. The PB aqueous extracts treated group showed significant reduction of blood glucose level compared to the diabetic control groups. The treatment with glipizide as a standard drug significantly decreases the blood glucose level. The leaves of the PB aqueous extract at $0.2 \mathrm{~g} / \mathrm{kg}$ and $0.5 \mathrm{~g} / \mathrm{kg}$ show decrease of blood glucose level significantly by $59 \%$ and $66 \%$ respectively. Whereas the stem PB aqueous extract in both doses shows a significant decrease of $54 \%$ and $65 \%$ in the blood glucose level. Meanwhile, the roots of the PB aqueous extract in both doses show a significant decrease of $53 \%$ and $55 \%$ in the blood glucose level. The reduction of glucose level might be due to the presence of apigenin $6 \mathrm{C}$ glucoside and chrysin in the PB aqueous extract. Luisa, et al. \& Cazarolli, et al. [16] have shown that the apigenin-6C- $\beta$-fucopyranoside from Averrhoa carambola possess an antihyperglycemic activity. Similarly, Boudjelal, et al. [17] have reported that apigenin reduced the glucose level in alloxan induced rats. Many reports have shown that chrysin possesses antihyperglycemic activity [16-22]. These finding provide convincing evidence that the effect of the PB aqueous extract in reducing the glucose level is due to the presence of apigenin 6c-glucoside and chrysin. Tissue proteins are known to contribute to body weight [23]. The decrease in body weight has been associated with diabetes mellitus due to the excessive breakdown of tissue protein and this could be due to catabolism of fats and protein $[24,25]$. The breakdown of adipocytes and muscle tissues in alloxan induced rats was due to frequent urination and the conversion of glycogen to glucose [26] In this study, the decreased in body weight was observed during the treatment of diabetic rats with PB aqueous extracts and glipizide as a standard drug. The results in Figure 2 show that the body weight of diabetic control groups decreased significantly compared with $\mathrm{PB}$ aqueous groups. These results reveal that $\mathrm{PB}$ aqueous extracts have an anabolic effect on the degeneration of adipocytes and muscle tissue by enhancing glucose metabolism. In the liver function test (Table 3), the changes in the concentration of enzymes alanine aminotransaminase (ALT), serum aspartate aminotransaminase (AST), and alkaline phosphatase (ALP) are measured in normal and alloxan induced diabetic rats during 25 days of treatment. These enzymes worked as liver markers, which are associated with various disorders that have an effect on liver tissue function. Moreover, the increased in the activities of ALP during diabetes is an indication of tissue damage due to toxicant $[27,28]$. The analysis of the activities of these enzymes in the serum was used to observe the condition of liver tissue and any damage might occur after being exposed to a certain pharmacological agent such as Alloxan [29]. In these studies, the treatment of diabetic rats with glipizide as a standard drug gave a significant reduction in the activity of these enzymes in the serum compared to diabetic control rats. The reductions in serum enzyme activities may indicate that the inhibition of liver damage was induced due to alloxan caused by treatment with PB aqueous extracts and glipizide. Insulin is a potent inhibitor of lipolysis. When the level of insulin decreased in alloxan induced diabetic rats due to $\beta$ cell damage, the mobilization of free fatty acids from the peripheral fat deposit through the activity of hormone sensitive lipase was increased [30]. Diabetes associated with the alteration in plasma lipid and lipoprotein profile increases the risk of coronary heart disease [31-37]. The level of lipid profile such as total cholesterol (TC), triglycerides (TG), LDL-cholesterol and HDL-cholesterol level have always been used to observe any risk in cardiovascular disorder like coronary heart disease. In this study, the lipid profile (Table 3 ) showed that the levels of total cholesterol (TG), triglycerides and LDL in alloxan induced diabetic rats treated with PB aqueous extracts and glipizide as a standard drug have significantly decreased compared to diabetic control rats. While the HDL level in the plasma showed significant increase as compared to the diabetic control rats. The results show that the level of total cholesterol, triglycerides and LDL are maintained compared with normal control groups. This indicates that the PB aqueous extract has an effect on the pancreas to produce insulin and inhibits the hormones sensitive lipase activity in the adipose tissue and controls the released of fatty acid during the regulation of glycogen metabolism. Thus, these results indicate that the Pereskia bleo aqueous extracts possess antioxidant and antidiabetic effects attributed to the presence of apigenin 6C-glucoside and chrysin in the aqueous extract (Figure 3). 


\begin{tabular}{|c|c|c|}
\hline Sample & Total Phenol (mg GAE/g) & Total Flavonoid (mg QE/g) \\
\hline Leaves aqueous & $2.77 \pm 0.05$ & $1.66 \pm 0.54$ \\
\hline Stems aqueous & $6.05 \pm 0.10$ & $7.86 \pm 0.07$ \\
\hline Root aqueous & $3.51 \pm 0.71$ & $2.15 \pm 0.14$ \\
\hline
\end{tabular}

Each value of phenolic and flavonoid contents indicates as means + SEM.

Table 1: Total phenols and flavonoids content of Pereskia bleo extracts.

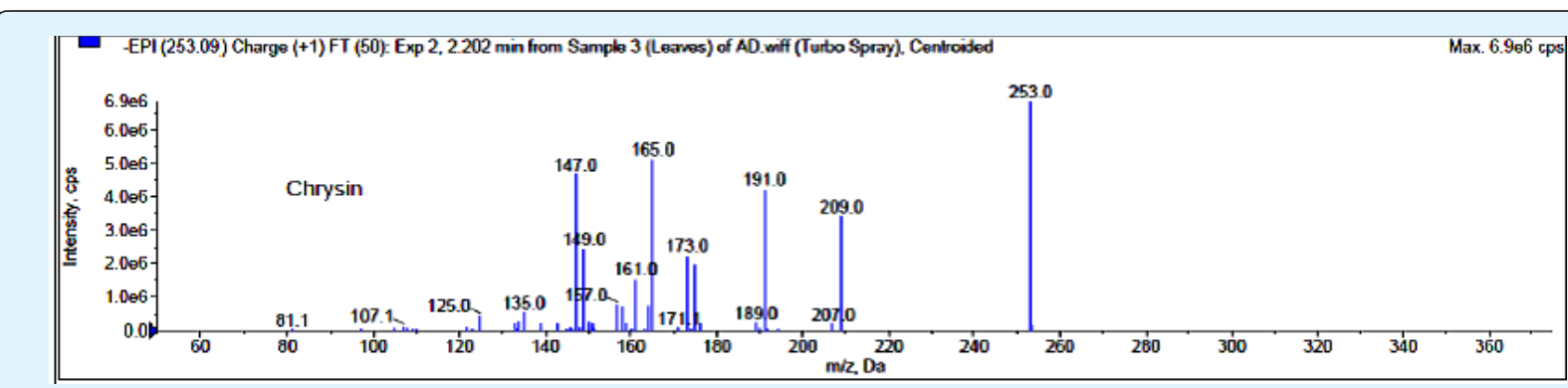

a)

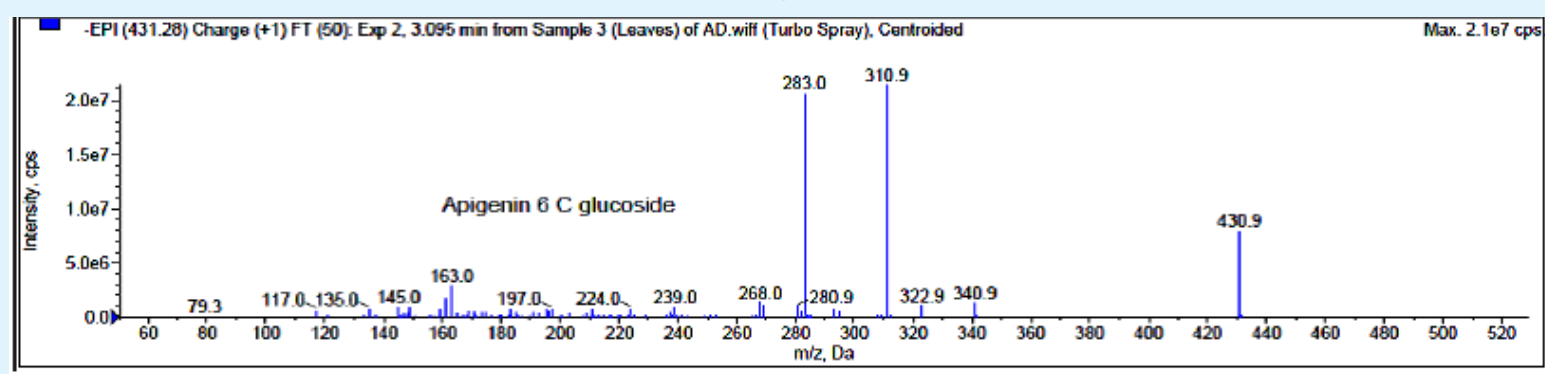

b)

Figure 1: LCMS/MS profile of a) Chrysin and b) Apigenin 6C glucoside.

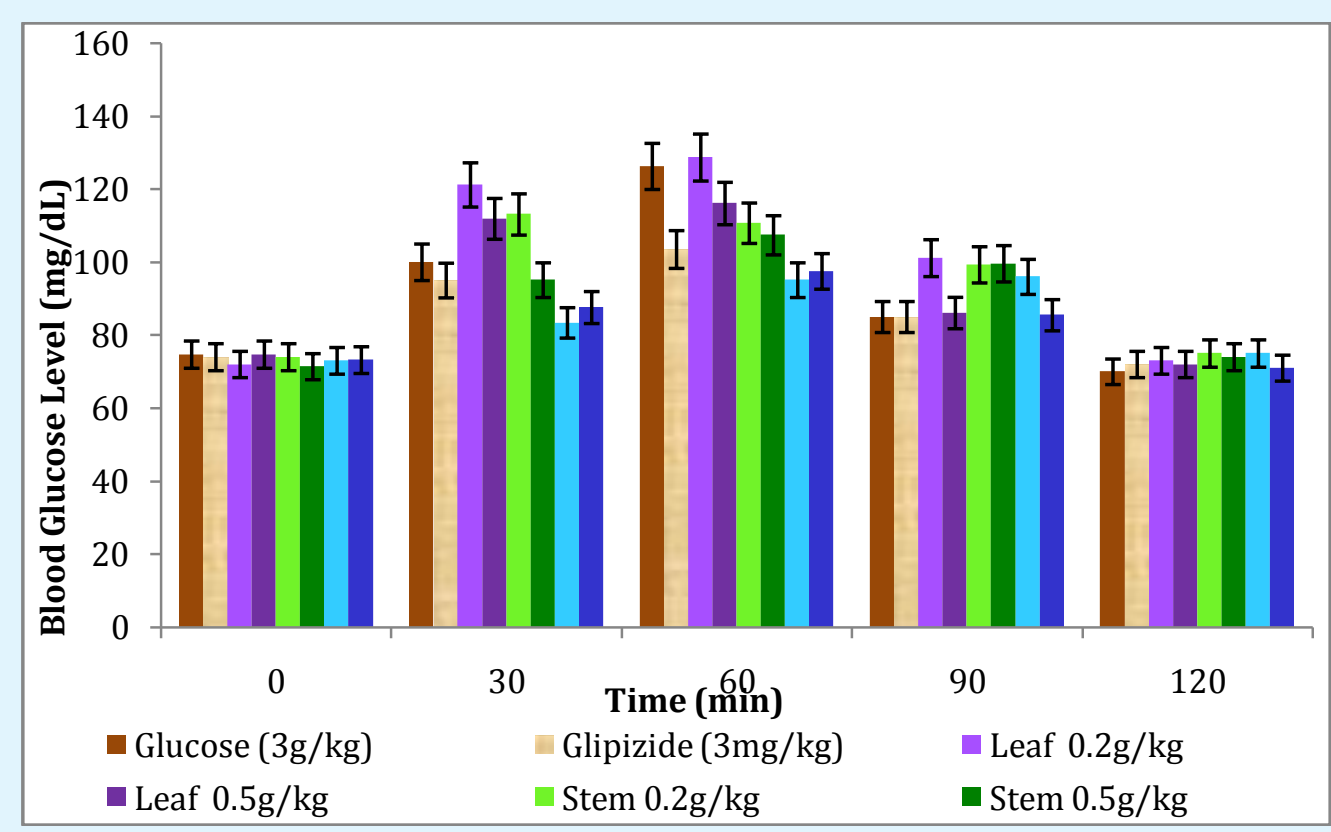

Figure 2: Blood glucose level after administrated with aqueous Pereskia bleo extracts and glucose in OGTT. Each value is mean \pm SEM of six animals $(n=6)$. 


\begin{tabular}{|c|c|c|c|c|c|c|}
\hline \multirow{2}{*}{ Group } & \multicolumn{7}{|c|}{ Blood Glucose Level (mg/dL) } \\
\cline { 2 - 7 } & Day 0 & Day 5 & Day 10 & Day 15 & Day 20 & Day 25 \\
\hline 1. Normal Control & $75 \pm 11$ & $78.5 \pm 13$ & $74.5+10$ & $76.8 \pm 14$ & $79.2 \pm 11$ & $78 \pm 10$ \\
\hline 2. Diabetic Control & $284 \pm 17$ & $312 \pm 15$ & $359 \pm 11$ & $375 \pm 10$ & $385 \pm 16$ & $380 \pm 15^{*}$ \\
\hline 3. Glipizide.(3mg/kg) & $285+11$ & $280+19$ & $260 \pm 19$ & $270 \pm 19$ & $265 \pm 12$ & $260 \pm 14^{*}$ \\
\hline 4. Leaf (0.2g/kg) & $284 \pm 16$ & $231+17$ & $185 \pm 13$ & $128 \pm 16$ & $119 \pm 13$ & $115 \pm 10^{*}$ \\
\hline 5.Leaf (0.5g/kg) & $286 \pm 13$ & $263+17$ & $205 \pm 18$ & $160 \pm 14$ & $99 \pm 10$ & $97 \pm 10^{*}$ \\
\hline 6. Stem (0.2g/kg) & $281+11$ & $178+13$ & $193 \pm 11$ & $187 \pm 14$ & $160 \pm 12$ & $129 \pm 11^{*}$ \\
\hline 7. Stem (0.5g/kg) & $284 \pm 13$ & $182+19$ & $173 \pm 12$ & $149 \pm 10$ & $119 \pm 19$ & $99 \pm 12^{*}$ \\
\hline 8. Root (0.2g/kg) & $283+12$ & $207+19$ & $190 \pm 12$ & $181 \pm 18$ & $146 \pm 10$ & $131 \pm 16^{*}$ \\
\hline 9. Root (0.5g/kg) & $285 \pm 15$ & $195+18$ & $126 \pm 16$ & $113 \pm 16$ & $120 \pm 10$ & $120 \pm 19^{*}$ \\
\hline
\end{tabular}

The sign $(*)$ indicated values significantly different from the diabetic control group at $\mathrm{p}<0.05$.

Table 2: Effect of Pereskia bleo aqueous extracts in fasting blood glucose level of diabetic rats.

\begin{tabular}{|c|c|c|c|c|c|c|c|}
\hline \multirow{2}{*}{ Sample } & \multicolumn{3}{|c|}{ Liver Function Test (U/L) } & \multicolumn{4}{c|}{ Lipid Profile Test (mmol/L) } \\
\cline { 2 - 7 } & ALT & AST & ALP & TRIG & T.CHOL & HDL & LDL \\
\hline Normal Control & $54 \pm 8$ & $40 \pm 2$ & $39 \pm 5$ & $0.7 \pm 1$ & $1.5 \pm 0.2$ & $1.3 \pm 0.1$ & $0.5 \pm 0.1$ \\
\hline Diabetic Control & $97 \pm 8$ & $94 \pm 4$ & $89 \pm 3$ & $1.9 \pm 2$ & $2.3 \pm 0.1$ & $0.5 \pm 0.1$ & $1.1 \pm 0.1^{*}$ \\
\hline Glipizide $(3 \mathrm{mg} / \mathrm{kg})$ & $59 \pm 3$ & $44 \pm 5$ & $37 \pm 2$ & $0.5 \pm 1$ & $1.5 \pm 0.1$ & $1.5 \pm 0.1$ & $0.3 \pm 0.1^{*}$ \\
\hline Leaf $(0.2 \mathrm{~g} / \mathrm{kg})$ & $52 \pm 3$ & $47 \pm 3$ & $39 \pm 4$ & $0.6 \pm 0.1$ & $1.7 \pm 0.3$ & $1.9 \pm 0.1$ & $0.6 \pm 0.1^{*}$ \\
\hline Leaf $(0.5 \mathrm{~g} / \mathrm{kg})$ & $59 \pm 6$ & $41 \pm 6$ & $34 \pm 6$ & $0.4 \pm 0.1$ & $1.6 \pm 0.1$ & $1.2 \pm 0.2$ & $0.5 \pm 0.2^{*}$ \\
\hline Stem $(0.2 \mathrm{~g} / \mathrm{kg})$ & $62 \pm 5$ & $44 \pm 5$ & $36 \pm 5$ & $0.6 \pm 0.1$ & $1.7 \pm 0.3$ & $1.9 \pm 0.1$ & $0.6 \pm 0.1^{*}$ \\
\hline Stem $(0.5 \mathrm{~g} / \mathrm{kg})$ & $54 \pm 9$ & $49 \pm 3$ & $36 \pm 3$ & $0.6 \pm 0.1$ & $1.6 \pm 0.1$ & $1.1 \pm 0.2$ & $0.5 \pm 0.1^{*}$ \\
\hline Root $(0.2 \mathrm{~g} / \mathrm{kg})$ & $58 \pm 1$ & $46 \pm 6$ & $33 \pm 6$ & $0.7 \pm 0.1$ & $1.8 \pm 0.1$ & $1.8 \pm 0.1$ & $0.7 \pm 0.1^{*}$ \\
\hline Root $(0.5 \mathrm{~g} / \mathrm{kg})$ & $60 \pm 6$ & $42 \pm 3$ & $32 \pm 3$ & $0.6 \pm 0.2$ & $1.5 \pm 0.1$ & $1.8 \pm 0.1$ & $0.5 \pm 0.1^{*}$ \\
\hline
\end{tabular}

The sign $(*)$ indicated values significantly different from the diabetic control group at $\mathrm{p}<0.05$.

Table 3: Lipid profile and liver functions profile of diabetic rats treated with Pereskia bleo aqueous extract.

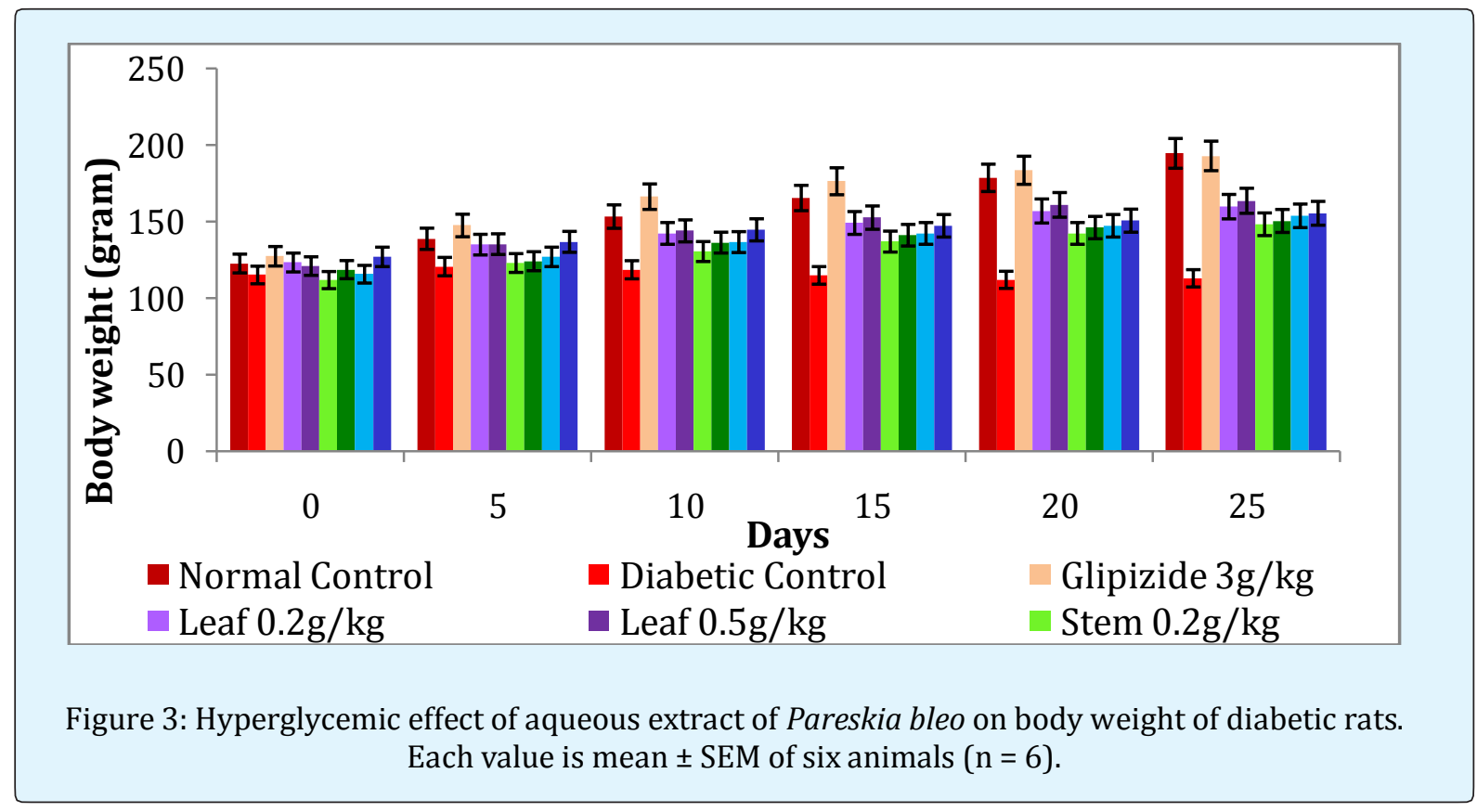




\section{Open Access Journal of Pharmaceutical Research}

\section{Conclusion}

The aqueous extracts of leaves, stems and roots of Pereskia bleo contain phenol, flavonoid and terpenoid compounds.The LCMS/MS showed that the presence of apigenin 6C-glucoside and chrysin.It showed no toxic effect of Pereskia bleo on male rats. Furthermore, the leaves, stem and roots of the aqueous extract reduced the glucose level significantly at the concentration of $500 \mathrm{mg} / \mathrm{kg}$ in diabetic rats. In addition, the leaves, stems and roots aqueous extract also decreased the trigliserides and total cholesterol level in diabetic rats while the level of HDL is maintained compared with the control rats. Thus, the results obtained from this study provide novel evidence in supporting the traditional uses of Pereskia bleo as an antidiabetic remedy for the treatment of diabetes.

\section{References}

1. Ernst E (1997) Plants with hypoglycemic activity in humans. Phytomedicine 4(1): 73-78.

2. Itankar PR, Lokhande SJ, Verma PR, Arora SK, Sahu RA, et al. (2011) Antidiabetic potential of unripe Carissa carandas Linn fruit extract. J Ethnopharmacol 135(2): 430-433.

3. Tan MJ, Ye JM, Turner N, Behrens $\mathrm{CH}, \mathrm{Ke} \mathrm{CQ}$ et al. (2008) Antidiabetic Activities of Triterpenoids Isolated from Bitter Melon Associated with Activation of the AMPK Pathway. Chemistry \& Biology 15(3): 263-273.

4. Zhou J, Zhou S, Tang J, Zhang K, Guang L, et al. (2009) Protective effect of berberine on beta cells in streptozotocin- and high-carbohydrate/high-fat dietinduced diabetic rats. Eur J Pharmacol 606(1-3): 262268.

5. Khor PY, Mohd Syafiq A, Suryati S, Shaarmini KR, Che Amal Hayati CY (2013) A preliminary survey on the medicinal uses and effectiveness of Pereskia bleo used by people of three villages in the state of Kelantan, Malaysia. Int J Herb Med 1(3): 1-4.

6. Yusof SF (2010) Herbal plant around us. Ar-Risalah Product Sdn. Bhd. Selangor, Malaysia. 120.

7. Erika J, Edwards MJ, Donoghue (2006) Pereskia and the origin of cactus life-form. Am Nat 167.

8. Sri Nurestri AB, Norhanom AW, Hashim Y, Sim KS, Hong SL, et al. (2008) Cytotoxic activity of Pereskia bleo (Cactaceae) against selected human cell lines. Int J Cancer Res 4(1): 20-27.

9. Sim KS, Sri Nurestri AM, Sinniah SK, Kim KH, Norhanom AW (2010) Acute oral toxicity of Pereskia bleo and Pereskia grandifolia in mice. Pharmacogn Mag 6(21): 67-70.

10. Behnaz H, Azizah AH, Roheeyati AM, Noriha, MS, Ahmad SA, et al. (2012) Antioxidant activity of different extracts from leaves of Pereskia bleo (Cactaceae). J Med Plants Res 6(15): 2932-2937.

11. Sim KS, Sri NAM, Norhanom AW (2010) Phenolic content and antioxidant activity of crude and fractionated extracts of Pereskia bleo (Kunth) DC. (Cactaceae). Afr J Pharm Pharmacol 4(5): 193-201.

12. Spanos GA, Wrosltad RE (1990) Influence of processing and storage on the phenolic composition of Thompson seedless grape juice. J Agric Food Chem 38(7): 1565-1571.

13. Liu B, Zhu Y (2013) Extraction of flavonoids from flavonoid-rich parts in tartary buck wheat and identification of the main flavonoids 2007. J Food Eng 78(2): 584-587.

14. OECD 423 (2001) OECD guidelines for testing of chemical acute oral toxicity-acute toxic class method adopted: 17th December 2001.

15. Shiwaikar A, Rajendran K, Barik R (2006) Effect of aqueous bark extract of Garuga pinnata Roxb, in strptozotocin-nicotinamide induced type II diabetes mellitus. J Ethnopharmacol 107(2): 285-290.

16. Cazarolli LH, Kappel VD, Pereira DF, Moresc HH, Brighente IM, et al. (2012) Anti-hyperglycemic action of apigenin-6-C- $\beta$-fucopyranoside from Averrhoa carambola. Fitoterapia 83(7): 1176-1183.

17. Boudjelal A, Siracusa L, Henchiri C, Sarri M, Abderrahim B, et al. (2015) Antidiabetic Effects of Aqueous Infusions of Artemisia herba-alba and Ajuga iva in Alloxan-Induced Diabetic Rats. Planta Med 81(9): 696-704.

18. Premalatha M, Parameswari CS (2012) Renoprotective effect of chrysin (5,7 dihydroxy flavone) in streptozotocin induced diabetic nephropathy in rats. Int J Pharm Sci 4(3): 241-247.

19. Satyanarayana K, Sravanthi K, Shaker IA, Ponnulakshmi R, Selvaraj J (2015) Role of chrysin on 


\section{Open Access Journal of Pharmaceutical Research}

expression of insulin signaling molecules. J Ayurveda Integr Med 6(4): 248-258.

20. Cheng N, Yi WB, Wang QQ, Peng SM, Zou XQ (2014) Synthesis and a-glucosidase inhibitory activity of chrysin, diosmetin, apigenin, and luteolin derivatives. Chin Chem Lett 25(7): 1094-1098.

21. Anitha T, Rajadurai M (2015) Evaluation of biochemical profile of chrysin in streptozotocinnictonimaide induced diabetic rats. Int J Pharm Bio Sci 6(1): 905-912.

22. Lukacinova A, Mojzis J, Benacka R, Keller R, Maguth T (2008) Preventive Effects of Flavonoids on AlloxanInduced Diabetes Mellitus in Rats. Acta Vet Brno 77(2): 175-182.

23. Rajkumar L, Srinivasan N, Balasubramanian K, Govindarajulu P (1991) Increased degradation of dermal collagen in diabetic rats. Indian J Exp Biol 29(11): 1081-1083.

24. Kamalakkannan N, Prince PS (2006) Antihyperglycaemic and antioxidant effect of rutin, a polyphenolic flavonoid, in streptozotocin-induced diabetic wistar rats. Basic Clin Pharmacol Toxicol 98(1): 97-103.

25. Hakim ZS, Patel BK, Goyal RK (1997) Effects of chronic ramipril treatment in streptozotocin-induced diabetic rats. Indian J Phys Pharmacol 41(4): 53-60.

26. Lin JK, Lin Shiau SY (2006) Mechanisms of hypolipidemic and anti-obesity effects of tea and tea polyphenols. Mol Nutr Food Res 50(2): 211-217.

27. Ravikumar R, Krishnamoorthy P, Kalidoss A (2010) Antidiabetic and Antioxidnt efficacy of Andrographis paniculata in Alloxanized Albino rats. Intl J Pharm Technol 2(4): 1016-1027.

28. Uboh FE, Iniobong EO, Ekong MB (2010) Effect of Aqueous Extract of Psidium guajava Leaves on Liver Enzymes, Histological Integrity and Haematological Indices in Rats. Gastroenterol Res 3(1): 32-38.
29. Eze ED, Dawud FA, Zainab AA, Jimoh IS, Malgwi, et al. (2012) Preliminary Studies of Effects of Vitamin C and Zinc on Some Liver Enzymes in Alloxan-induced Diabetic Wistar Rats. Asian J Med Sci 4(1): 17-22.

30. Mbaka GO, Ogbonnia SO, Banjo AE (2012) Activity of Raphia hookeri root extract on blood glucose, lipid profile and glycosylated haemoglobin on alloxan induced diabetic rats. J Morphol Sci 29(3): 214-222.

31. Huang YC, Chang PY, Hwang JS, NingHC (2014) Association of Small Dense Low - density Lipoprotein Cholesterol in Type 2 Diabetics with Coronary Artery Disease. Biomed J 36(2): 375-379.

32. Goldener MG, Gomori G (1944) Studies on the mechanism of alloxan diabetes. Endocrinology 35(4): 241-248.

33. Shankar MB, Parikh JR, Geetha M, Mehta RS, Saluja AK (2007) Anti-diabetic activity of novel androstane derivatives from Syzygium cuminii Linn. J Nat Remedies 7(2): 214-219.

34. Simonian NA, Coyle JT (1996) Oxidative stress in neurodegenerative disease. Ann Rev Pharmacol Taxicol 36: 83-106.

35. Solomon RBG, Ganga RB, Manju LYB (2012) Andiabetic activity of Smilax china roots in alloxaninduced diabetic rats. Int J PharmTech Res 4: 369374.

36. Malek SN, Shin DK, Wahab NA, Yaacob H (2009) Cytotoxic Components of Pereskia bleo (Kunth) DC. (Cactaceae)Leaves. Molecules 14(5): 1713-1724.

37. Viana GS, Medeiros AC, Lacerda AM, Leal LK, Vale TG, et al. (2004) Hypoglycemic and anti-lipemic effects of the aqueous extract from Cissus sicyoides. BMC Pharmacol 8: 4-9. 